\title{
The chronic patient in face of falling ill and the treatment compliance* $^{*}$
}

\author{
Paciente crônico frente ao adoecer e a aderência ao tratamento \\ El paciente crónico frente al adolecer y la adherencia al tratamiento
Caroline de Leon Linck ${ }^{1}$, Valquíria de Lourdes Machado Bielemann ${ }^{2}$, Afra Suelene de Sousa ${ }^{3}$, Celmira Lange ${ }^{4}$

\begin{abstract}
Objective It has, as its purpose, to know these patients' perceptions on the reasons that make them comply, or not, with the treatment. Methods: Qualitative descriptive approach, with five inpatients at a Medical Clinic Unit in a university hospital in Southern Brazil. Results: The data were collected in semi-structured interviews and analyzed when three themes were present: perception of the disease, importance of the therapeutics and difficulty to perform the therapeutics. Conclusion: It was made evident that, when complying with the treatment, there are several factors involved that add to the complexity of this issue, being related to people's behavior and their motivations, and becoming an important challenge to be overcome by the healthcare professionals.

Keywords: Chronic disease/therapeutics; Qualitative research; Nursing care
\end{abstract}

\section{RESUMO}

Objetivo: Conhecer a percepção desses pacientes sobre os motivos que os levam a aderir, ou não, ao tratamento. Métodos: Em relação à metodologia, foi empregada uma abordagem qualitativa e descritiva, com cinco sujeitos hospitalizados em uma Unidade de Clinica Médica de um Hospital Universitário do Sul do Brasil. Resultados: Quanto aos resultados, os dados foram coletados através de entrevista semiestruturada e analisados quando surgiam três temas: a percepção da doença; a importância da terapêutica e a dificuldade de realização da terapêutica. Conclusão: Assim, evidenciou-se que, na aderência ao tratamento, existe uma diversidade de fatores envolvidos que tornam essa questão complexa, tendo relação com o comportamento das pessoas e suas motivações, tornando-se um grande desafio a ser enfrentado pelos profissionais de saúde.

Descritores: Doença crônica/terapia; Pesquisa qualitativa; Cuidados de enfermagem

\section{RESUMEN}

Objetivo: Conocer la percepción de esos pacientes sobre los motivos que los llevan a adherirse, o no, al tratamiento. Métodos: En relación a la metodología, fue empleado un abordaje cualitativo y descriptivo, con cinco sujetos hospitalizados en una Unidad de Clínica Médica de un Hospital Universitario del Sur del Brasil. Resultados: En cuanto a los resultados, los datos fueron recolectados a través de una entrevista semi-estructurada y analizados surgiendo tres temas: la percepción de la enfermedad; la importancia de la terapéutica y la dificultad de realización de la terapéutica. Conclusión: Así, se evidenció que, en la adherencia al tratamiento, existe una diversidad de factores involucrados que vuelven compleja a esa cuestión, teniendo relación con el comportamiento de las personas y sus motivaciones, volviéndose un gran reto a ser enfrentado por los profesionales de salud.

Descriptores: Enfermedad crónica/terapia; Investigación cualitativa; Cuidados de enfermería

\footnotetext{
* Research performed in the Medical Clinic Unit of a university hospital in Santa Catarina, partner of UFPel.

1 Specialist, substitute professor of the Nursing and Obstetrics College of the Federal University of Pelotas - UFPel (RS), Brazil

${ }^{2}$ Master of Sciences, Adjunct Professor of the Nursing and Obstetrics College of the Federal University of Pelotas - UFPel (RS), Brazil

${ }^{3}$ Master of Sciences, Adjunct Professor of the Nursing and Obstetrics College of the Federal University of Pelotas - UFPel (RS), Brazil

${ }^{4}$ PhD, Adjunct Professor of the Nursing and Obstetrics College of the Federal University of Pelotas - UFPel (RS), Brazil
} 


\section{INTRODUCTION}

This study is focused in part of the universe of the chronic, diabetic and hypertensive patients, trying to reveal the problems experienced by these human beings in order to contribute to the improvement of quality of the healthcare provided, and the patient's own quality of life. This research is justified by studies pointing to increasing numbers of people with chronic and degenerative diseases, becoming a very serious social problem to be faced by healthcare professionals.

According to a study published in 2005 by the Brazilian Institute of Geography and Statistics - IBGE ${ }^{(1)}$, in partnership with the Ministry of Health, almost 53 million Brazilians ( $30 \%$ of the population) are affected by diabetes, hypertension, rheumatism, tendonitis, muscle pain, back pain or respiratory problems. Women are most frequently victims $(33.9 \%)$ of the so-called chronic diseases; men make up $25.7 \%$ of the total victims. The study also shows that the amount of people with chronic diseases is higher in classes with higher family incomes, as well as in people older than 40 years.

The discussion of chronic diseases is strengthened, showing that the separation and the problematic of such afflictions, in particular diabetes mellitus, is the fact that they are long-term diseases, capable of leading to significant aggravations such as limb amputation and eye damage. A continuous, strict treatment is necessary, especially with people over 40 years of age, considered a risk group, and diabetic or hypertensive people, since they are vulnerable to complications ${ }^{(2)}$, in accordance with the data from the IBGE study.

Chronic diseases, when not diagnosed and treated early, may lead to serious aggravations or even death, especially because they are long-term maladies, limiting and with a high risk of complications. However, people should bear in mind that the aggravations may be lowered if the client receives adequate orientation about his condition and the possible complications ${ }^{(3)}$. Therefore, having chronic patients to comply with effective treatments is a constant challenge to the Nursing professionals, who have been performing several actions to try to revert this situation, such as providing public lectures, forming groups of discussion and offering nursing appointments.

In face of what was discussed, a 2006 journal reveals that the impact of chronic diseases in worldwide economy in 2020 may reach $65 \%$ of the healthcare costs. It is calculated that about $50 \%$ of the patients with chronic diseases in developed countries did not significantly comply with the therapeutics behavior, negatively impacting both the patient and the State ${ }^{(4)}$.

All these reflections converged towards the completion of a study so that favorable strategies could be pointed out, in order to improve the patient's motivation to comply with the treatment. Furthermore, it would make it possible to get to know the chronic patient better - diabetic and/or hypertensive discovering their most relevant difficulties, both internal and external, in face of the disease and increasing knowledge about such diseases. Therefore, questions were sought so that the perception of chronic patients about the reasons that led them to comply or not with the treatment could be known, verifying their knowledge of aggravation risks and identifying the difficulties that they face to comply with the treatment.

\section{METHODS}

This research is a qualitative study, since it intends to produce a subjective, non-quantified approach, focused on the subjects' way of thinking ${ }^{(5)}$.

This research was performed in the Medical Clinic Unit of a University Hospital in one of the Southern states of Brazil. The subjects of the study were five patients with chronic diseases, such as diabetes and/or hypertension, over 18 years of age and who had been admitted to the hospital due to aggravations caused by said diseases. They were named after planets, according to their own choice, so as to keep anonymity: Mars, Saturn, Jupiter, Earth and Venus.

The choice of subjects started by looking at the inpatients' medical records in the aforementioned Unit, with 10 patients being identified with diabetes mellitus (DM) or systemic arterial hypertension (HAS) after a short analysis. Five subjects were then randomly drawn from the group. Of these, Mars, Jupiter and Venus had both diseases. Saturn had diabetes mellitus and Earth had HAS.

In the first meeting, the introduction of the researcher, the project and patient sensitization were achieved. In the second meeting, previously scheduled, there was the invitation to participate of the research. After all the invited patients acquiesced, three further meetings were held with each subject.

The interviews were had in these meetings, being semi-structured and made up of four questions: What do you know about your disease? Which treatment was prescribed to you? Explain how you performed it. What is your opinion about this treatment? What were the facilities and difficulties to follow the treatment? Justify.

Semi-structured interviews were used because they are not rigid and allow for restructuring, according to the needs of the researcher ${ }^{(6)}$. At the end of the research, a meeting was held with all the participants and the healthcare team of the institution, in order to thank them for their collaboration, discuss the problematic of the chronic diseases with the group, and also, to validate the 
study.

The ethic principles guiding this study were backed by the Code of Ethics of the Nursing Professionals from $2001^{(7)}$ and Resolution 196/96 of the Ministry of Health National Healthcare Council ${ }^{(8)}$, which deals with research involving human beings. Such rights were mentioned in the term of consent, handed out and signed by all the participants. The data were collected after approval by the Review Board of the Federal University of Pelotas - RS. The gross results emerging from data collection were analyzed in three stages: pre-analysis, data exploration and interpretation, extracting the main ideas to arrive at the themes that are directly related to the study's proposal ${ }^{(5)}$.

\section{RESULTS}

The results were contained in three themes: the perception of the disease, the importance of the therapeutics and difficulty of accomplishment of the therapeutics.

\section{The perception of the disease}

In this theme it happens the interpretation of the situations and feelings for the subject of the study, in other words, the construction of meanings front to the disease, starting from the interpretation of the lived situation. The verbalizations that come to proceed, in our understanding, translate the initial path lived by the subject of the research, front to the illness, their interpretations on noticing the disease and, consequently, acting front to the situation.

I took the medication for less than a year, because I didn't feel anything. The treatment for blood pressure was the same as diabetes, I didn't feel anything, so I stopped doing it. I thought I didn't need to do it anymore, so I didn't, and since I didn't feel anything, I thought I was cured. I only felt it when I came down here (talking about the hospital). Now I'm going to take care of myself, take the medication and follow the diet. (Venus).

I think diabetes is a dangerous disease, because it corrodes the person until the person feels it when he's really deep down the batch. And we also go easy on the treatment, sometimes you take the meds, sometimes you don't, and time goes by, and when you want to take care of yourself it's too late [...] No one has ever explained how diabetes works inside my organism. (Saturn).

I thought that if I took it for a week, or two, and my blood pressure got lower, I wouldn't need to take it anymore. Maybe I haven't understood it well in the first appointments, that it really had to be regular, non-stop. (Earth).

\section{The importance of therapeutics}

The importance given to the treatment is expressed below, with the observance of an emphasis on pharmacologic therapeutics as the main factor for the maintenance of health, such as dietary control, physical activity, and even recreational activities, which can be concomitant, making a healthier life possible without the threat of aggravation.

It's been sort of two years I've been taking it correctly, I don't skip on it, if I can't find it in the health station, I'll buy it. I was never too careful about dieting, I tried to use less salt in the food but I wasn't too strict on it. (Earth).

They gave me lots of kinds of medicine, exercise, they also told me to walk a lot and to go on a diet. But you know how we are, don't you. All my life I'd really stick to taking the medication, I'd take it to bed with a glass of water and I'd take it every day at 6 AM, and after 5 PM too, I was really constant on that, but for the rest, the food, I'm not that constant. (Saturn).

In the beginning they gave me medicine, but I don't know which ones, the health station gave them to me - I took them for some time, afterwards I didn't take it any more, he gave me a diet and exercise, but I wouldn't do it, I thought it wasn't bad [...] Now I'm gonna take good care of myself, take the medicine all right and go on a diet. (Venus).

\section{Difficulties to perform the therapeutics}

In the last theme, it can be verified, in the verbalizations of the subjects, that the main difficulties are associated to follow an appropriate diet and to practice exercises regularly. However, the largest difficulties are related to the acceptance of the feeding and to the physical activity, as we can verify in the verbalizations:

I used to do a little dieting, because we don't do it by ourselves, don't you know, there's no one to do it for us. I'd take the medication, but sometimes I'd get one by mistake, sometimes, asked someone, some other, but I'd take it [...] When my wife was alive, I followed the treatment better because she helped me out. (Jupiter).

The hardest of all is only 2 people, like, putting 4 or 5 pots on the stove, cooking just a little bit in each pot which would be left over, so we were used to a little bit of rice today, a little bit of porridge tomorrow [...] It would be easier if the family was bigger, one eats, the other eats, and in no time all the pots are clean (Saturn).

About eating, on diabetes, I'd always tell her (his wife), if you cook it I'll eat it, a dessert, you know what I'm saying, and she'd do it, not every week but she'd do it, and also because of the children, you know what I'm saying? Food was spicy, not really regulated, not too salty but also not really right. (Mars).

\section{DISCUSSION}

In order to discuss the first theme, we felt the need to emphasize the reflection about perception, as being the way that the individuals understand, to themselves, 
the people that surround them, the situations their turn and their relationships with the world. Going to the encounter from what was said Travelbee, in his theory, he already referred to the perception as being the movement that happens inside of the individual, in order to understand the society his/her turn, revealing and relating it in agreement with their previous experiences ${ }^{(9)}$.

In that way, the perception of the disease has direct relationship with this context, also because the interpretation of the disease comes to be more than the presence of some pathology, involving the way as the individual shows himself in the society, the way as he links with himself own and with the other ones, his/her culture, the answer to their socioeconomic conditions and, mainly, the meaning that gives to the situation of disease.

In this sense, the same can say of the situation of disease or to get sick, because it is the way that the individual and the one that surround interpret him the cause and the relevance of the situation of disease, the alterations promoted in his/her daily one, and the several following cares to soften that ${ }^{(10)}$. The disease is part of the psychological, moral and social dimentions. Therefore, it is observed that each individual reacts from a singular way to the situation of disease, depending on the concept that he has been formulating on the issue ${ }^{(9)}$.

It can be inferred that Venus and Saturn, as they be attacked by a situation of disease, they live it in an own and singular way. In spite of, the conscience of the illness seems to be very harnessed to feel pain, to the physical incapacity. When it is not being lived, it is more difficult to feel the need to take care to maintain healthy, front to a future perspective. Consequently, we understood, as one of the main problems of the chronic disease, the lack of specific symptomatology in the beginning of the disease and, a lot of times, the delay to manifest, which, in general, it takes to a late perception on being sick. Like this, a distance exists among the discover of the illness and feeling sick. Such disparity, in our understanding, takes the person to a form of behavior and of acting not returned to the preservation of the health, which until it can explain the flaws in the treatment, as it is evidenced in the depositions.

It is evident that those patients don't associate the disease to their lives. They treat it as an external event, in other words, separated from the process of living, they are not aware that the disease will be part of their daily one, it tends in view that is chronic.

Many bearers of chronic diseases are not conscious of what is happening in his/her own body, because several symptoms can be described as normal of the run and stressful life, until that significant offences appear and justify the search of medical cares ${ }^{(10)}$. That argument reinforces our reflections.
It is very important to understand that, when it is a chronic disease, for the person to live with quality, he/ she needs to have conscience of the pathology. For so much, it is done necessary that he/she has access to a service, in which feels emphasis to the education in health, with perspective of creating new attitudes front to the disease.

The several professionals of health relationship, front to the patient, doesn't favor her/him to act communicative, therefore it is not efficient, and they don't contribute to the therapeutic relationship, as it is evidenced in the speeches of Saturn and Earth, to them they didn't have enough explanations on the action of those diseases, diabetes and hypertension, in the organism. The need of the education is evidenced for the health, that is seen as base to help the patient and his/her family to understand the chronic situation and the need of changes in their life habits.

As base for the development of an education in health, that is essential part of the nursing actions, with the objective of improving the individual's potentialities, to seek to a satisfactory health and to qualify the service $^{(11)}$;it is necessary to put in practice the communication. This is referred in the theory of Travelbee, as the process that allows the establishment of an interpersonal relationship with patient-family, in order to help them to overcome that moment of crisis and to look for a meaning in the suffering ${ }^{(9)}$.

The importance of the therapeutics, second theme, appears as valorization of the pharmacotherapy . Like this, the interviewees attribute importance, for the maintenance of the health, to the pharmaco use, not giving relevance to the other treatment forms.

We thought that the therapeutics comes to be everything that is accomplished with the objective of qualifying the life, through the promotion, of the prevention, of the rehabilitation, taking to the cure, softening the problem of health or avoiding the disease. Like this, in the search of the human beings' well-being, it is possible to incorporate several practices, as the use of medications, the practice of physical activities, the accomplishment of diets, the phytotherapy,music therapy, psychological or psychiatric, support among others. Everything that benefits the patient, as the fact of standing back of the stressful situations, to be with the people that he/she loves, to receive affection and affectivity is actions that can be seen as therapeutics. We detached that therapeutic adhesion is the extension in that the person follows the professionals of health recommendations, related to the adoption of the use of medicines, dietary cares and even changes in the lifestyle ${ }^{(12)}$. THE dictionary of Portuguese language talks about therapeutics as the same as therapy, in other words, it is to put in practice the appropriate means, to diminish 
or to cure the patient ${ }^{(13)}$.

For the maintenance of the health, it is occupation the adhesion to the treatment that, as he/she sees himself, it can include several therapeutics. However, for that to happen, it is necessary that the bearer of chronic disease is motivated. The motivation is a component of the human life that it favors the people in the search of better roads than they qualify their lives ${ }^{(14)}$.

It is noticed clearly in the speeches, the importance attributed to the use of the pharmacotherapy and the lack of attention, released to the exercises and the feeding. Three main reasons exist to feel the same importance for these elements: medicine, feeding and exercise.

In first place, they interact during the whole day in our organism and not to emphasize them, from the beginning, it can generate complications. In second place, the benefits promoted by the exercise can avoid more severe complications, once they have the power to prevent or to reduce the obesity; and, besides, that physical practice can be a way for which the chronic patient can demonstrate his/her control about his/her body and the life. And in third plan, the appropriate feeding is an unquestionable factor for the maintenance of the health and the prevention of offences ${ }^{(15)}$.

The subject of the adherence to the therapeutics has been discussed along the history by several authors and, nevertheless, it continues being considered one of the professionals of health great challenges, mainly in the cases of chronic illnesses, that cart modifications in the daily of the individual ${ }^{(10)}$.

We reinforced the importance of alerting those patient for the benefit of the accomplishment of the treatment in the most possible applied way, without leaving of side essential factors, as the accomplishment of a healthy diet and the physical, same practice of activities recognizing that the adaptation to the treatment goes by the different phases of the development of the disease. That takes us to an interpretation that some bearers of those diseases only adhere, significantly, to the treatment, when if they are threatened and they notice the risks that are running.

The treatment of the chronic disease, for having an indefinite accomplishment period and, a lot of times, to be of high cost, provokes obstacle to its materialization. In Jupiter's speech, the treatment compliance is seen to be more complicated, because it presents a significant visual deficit, since he is a widower and lives by himself. As such, sometimes he would mistake the medications or forget to take them, and has difficulties to cook, which led him to eat canned and preserved food, which is not recommended for patients with diabetes and hypertension.

For Saturn, difficulties are related to preparing food, because he lives with his wife and no one else. His lines allow the inference that it is not viable to follow the diet correctly. Saturn does not seem to be aware that it is not necessary to cook several types and quantities of food in order to have good eating habits, but to use the food adequately, corresponding to his needs of staying healthy.

Mars's difficulty to follow a diet is understandably significant, considered the main obstacle to comply with the treatment. A behavior disorder is observed, both by the patient and his family. It is necessary for the family to reorganize itself as a group, to face the situation of a chronic disease in its midst. Nevertheless, it is important to evaluate both sides: the patient's, who must learn to live with healthier habits, changing his old habits; and the family's, which needs to support the patient in these changes.

Following an adequate diet becomes one of the obstacles to comply with the treatment. When focusing dieting, it is necessary to observe that, for many people, "eating is one of the most important things in life, one of the greatest pleasures, a great compensation, or even a way to sublimate their problems"(17).

It is worth highlighting that chronic diseases can bring about disorders as a consequence of their complications, both on the patient and in the family, associated to social, economic and emotional factors that affect the whole family group directly involved with the problem.

To reinforce this theme even more, it is important to acknowledge that, in order to contribute to treatment compliance, the professionals need to be aware of the necessary challenge to face, since this is a difficult issue and it presents several interfaces ${ }^{(16)}$.

As such, there is some criticism that, when caring for diabetic patients, the nurses, as educators, direct their orientations to the chronic patients, who needs control, adapting to a new lifestyle. However, they forget to observe the patient's desires, the sociocultural values, and do not notice that they are singular subjects, capable of participating actively in this process of healthcare education $^{(18)}$.

The discussion of chronic patients complying with the treatment leads to a better understanding of the situation experienced by these individuals, who, due to chronicity, have to forfeit several pleasures and reevaluate their habits, adapting to a new routine of rules and limits.

\section{CONCLUSIONS}

It is observed that the patient's perception about the disease situation influences his treatment compliance, since, by not noticing oneself as sick, one does not perform the therapeutics adequately, or abandons it early on. Therefore, since chronic disease patients lack symptoms in the beginning, as their main characteristic, they tend not to recognize their health state as grave and 
that they need care.

It seems that feeling sick is perceived through experiencing the stages of the disease. As such, these human beings build the conception that it is necessary to change behaviors, even though they do not get around to do it, to keep living with quality.

Otherwise, it is understood that significant treatment compliance is linked to whatever they interpret as therapeutics. As such, they associate the use of medication as the main component for the maintenance of health and prevention of the complications, relegating the remaining behaviors to a secondary position, particularly healthy eating habits and physical exercise.

It is important to highlight that the authors consider that alerting chronic disease patients about the benefits of following the treatment efficiently is of utmost importance, without ignoring essential factors such as

\section{REFERENCES}

1. Instituto Brasileiro de Geografia e Estatística. Acesso e utilização dos serviços de saúde 2003. Brasilia (DF): IBGE; 2003. [citado 2005 Mai 31] Disponível em: www.Ibge.gov.br/home/presidencia/noticias/ poticia_ visualiza. Php?Id_noticia $=370$ \&id_pagina $=1$.

2. Marcon SS, Waidman MAP, Carreira L, Decesário MN. Compartilhando a situação de doença: o cotidiano de famílias de pacientes crônicos. In: Elsen I, Marcon SS, Silva MRS, organizadoras. O viver em família e sua interface com a saúde e a doença. Maringá: EDUEM; 2004. p.265-81.

3. Cunha S. Portador de diabetes tipo 1l: expectativas e atitudes no enfrentamento das complicações crônicas [monográfia]. Pelotas: UFPel; 2000. 60f .

4. Ratiopharm. Adesão terapêutica. Primeira norma de orientação clínica relativa à adesão terapêutica em patologias crônicas [texto na Internet]. Carnaxide,Portugal; Radiopharm; c. 2003. [citado 2006 Dez 12] Disponível em: http://www1.ratiopharm.com/pt/pt/pub/ empresa1/destaques/ades_o_terap_utica_.cfm

5. Minayo M, organizadora. Pesquisa social: teoria, método e criatividade. Petrópolis: Vozes; 1998.

6. Lüdke M, André MEDA. Pesquisa em educação: abordagens qualitativas. São Paulo: Editora Pedagógica e Universitária; c1986.

7. Conselho Regional de Enfermagem do Rio Grande do Sul, Brasil (RS). Código de Ética dos Profissionais de Enfermagem. Porto Alegre: COREN; 2001 p. 36-8.

8. Brasil. Ministério da Saúde. Conselho Nacional de Saúde.Resolução no 196/96 sobre pesquisa envolvendo seres humanos. Brasília: Ministério da Saúde; 1996.

9. Travelbee J. Intervención en enfermería psiquiátrica: el processo de la relacion de persona a persona. Colômbia: undergoing a healthy diet and practicing physical exercise.

It is relevant to understand the patients' behavior of non-compliance to the treatment. Therefore, there is an urgent need to comprehend their values, beliefs, economic and social situations, so that the healthcare professionals, the nurse in particular, can act communicatively with them, guiding them to realize the need to comply with the treatment, and, at the same time, see themselves as agents of change, which contributes to improving and maintaining their health.

Based in the present study, it is necessary for the healthcare team - again, the nurse, in particular - to understand that the patient is someone who has a particular culture, beliefs, fears and traditions, which many times interfere when adapting to a situation of chronicity. Thus, when receiving care, his individuality must be considered, with an interpersonal relation being necessary, whose empathy can be the essence of said inter-relation.

OMS; 1982.

10. Helman CG. Cultura, saúde e doença. 2a. ed. Porto alegre: Artes médicas; 1994.

11. Padilha M S, Silva DM, Borensteln MS. Enfermagem ambulatorial: O cliente em condição crônica de saúde. In: Santos I, Figueiredo NMA, Padilha MICS, Souza SROS, Machado WCA, Cupello AJ, organizadores. Enfermagem assistencial no ambiente hospitalar: realidade, questões, soluções. São Paulo: Atheneu; 2004. p. 159-78.

12. Sabaté E, editor, World Health Organization. Adherence to long-term therapies: evidence for action. Geneva : World Health Organization; 2003.

13. Ferreira ABH. Aurélio século XXI: o dicionário da língua portuguesa. 3a. ed. rev. E aum. Rio de Janeiro: Nova Fronteira; c1999. p. 1367-8.

14. Pasti MJ, Gir E; Dela Coleta JA. Perfil motivacional do enfermeiro atuante em um hospital geral do interior paulista. Rev Latinoam Enferm. 1999; 7(5): 33-41.

15. Nunes VS. Atividade física para diabéticos tipo I e II. In: Santana MG, organizadora. Teia de saberes em diabetes e saúde: um exercício de interdisciplinaridade. Pelotas: Gráfica da UFPel; 2002.

16. Fechio JJ, Malerbi FEK. Adesão a um programa de atividade física em adultos portadores de diabetes. Arq Bras Endocrinol Metab. 2004; 48(2): 267-75.

17. Bastos DS, Borenstein MS. Identificando os déficits de autocuidado de clientes hipertensos de um centro municipal de Saúde. Texto\& Contexto Enferm. 2004; 13(1):92-9.

18. Ataíde MBC, Pagliuca LMF, Damasceno MMC. Interrelação dos propósitos da teoria de Peplau com o cuidado ao diabético. Rev Bras Enferm. 2002; 55(6): 674-9. 